\title{
Bioethical Questions in Brazilian Scientific Research
}

\author{
Sonia Vieira \\ São Camilo University, São Paulo, Brazil \\ Email: soniavieira@merconet.com.br
}

Received 16 May 2014; revised 11 June 2014; accepted 10 July 2014

Copyright (C) 2014 by author and Scientific Research Publishing Inc.

This work is licensed under the Creative Commons Attribution International License (CC BY). http://creativecommons.org/licenses/by/4.0/

c. (i) Open Access

\begin{abstract}
It is considered here that the ethical behavior of the Brazilian scientific community leaves a lot to be desired. Motives for ethical lapses can be summed up by one only: the haste to grow at any price in order to earn prestige and wealth, setting at naught those who don't have the political support of the institution. With this intent, many researchers publish whatever they can, neglecting the fact that scientific research should serve the interests of the community-not their own.
\end{abstract}

\section{Keywords}

Ethics, Bioethics, Misconduct

The prevalent idea is that it is simply a question of personality whether or not a person behaves ethically. However, to adhere to this idea is to deny the effect of the social and cultural context on human behavior. It is undeniable that, under the influence of the said context, certain characteristics of personality are either improved or degraded and their expression either encouraged or repressed. It follows that, although the context may not determine an actual lack of ethics, it does contribute towards the manifestation of such a lack. What are the social and cultural factors which contribute towards the lack of ethics in Brazilian scientific research?

First, the number of researchers has increased during the last decades. Science is becoming ever more complex. It is therefore unlikely that the researcher who masters only one specific area of knowledge will look for work of another kind. There is a lot of competition among peers. This is healthy because the researcher is obliged to perfect himself, which in turn benefits society with a choice of the most apt. Nonetheless, fierce competition can lead to outright war and a total lack of ethics.

Secondly, there is the pressure to publish which, although it does not necessarily cause the researcher to treat ethical values with scorn, it can contribute to a lack of perspective on his part. Moreover, the need to publish is an incentive to the formation of teams of researchers who, instead of meeting to discuss a particular work, publish it in co-authorship. This allows for patronage, the exchange of favors, co-authorship by authority and the rise to positions and titles by unethical methods, all of which undermine the milieu. 
Thirdly, society has already come to understand that research is useful and consequently, in the eyes of the public, the figure of the researcher has changed. In the past, a researcher was usually a simple man, always busy at work in his laboratory; today he is a successful and well-travelled individual, who gives interviews on the media. Research, however, is merely a routine service which at best produces small advances that contribute to the great mass of existing scientific knowledge; but, in a burning desire to be noticed, the researcher may easily trip up and trample on ethics.

Bioethics is a word that was created to designate a discipline which has recourse to the biological sciences to improve the quality of human life. Man must promote the advance of knowledge in the areas of science and technology, but he must at the same time respect basic ethical principles in order to preserve universal harmony [1]. Originally, bioethics was directed more towards medicine than towards the other sciences [2]. The advance of knowledge in the bio-medical area, added to a long tradition of discussing ethics in this same area, makes some people think that bioethics is synonymous with medical ethics. What's more, themes linked to birth and death, such as reproduction, abortion, artificial life support and euthanasia all bring to mind the medical aspects of many dilemmas with which today's science challenges us. Nonetheless, bioethics goes way beyond medical ethics: it is concerned with the ethics of the sciences of life which, although they include human health, deal with human life as a whole, as well with as animal and vegetal life-in other words, all the issues related to life and the living [3].

Standardization, legislation and sanctions related to scientific research must be based on bioethics. It is necessary to establish clear concepts and to separate what is debatable from what must be brought under rule or is already legislated. Words such as liberty, rights, responsibility, and coercion, must be properly conceived so as to be understood clearly and precisely, without requiring the mobilization of each and everyone's moral discernment whenever a decision is to be taken. It is necessary to know when discourse and discussion in ethical terms are permitted and when the straightforward application of norms and laws is required.

Concepts are not always sufficient: often the force of law is necessary. We are in a world of conflicting interests, of aims to be reached, but also of ideas. It is an arduous task in any situation to distinguish between that which is debatable and that which must simply be obeyed. Legal rights exist and are understandable, but it is very difficult to arrive at a consensus about what is correct from the point of view of morals and ethics. People's rights are not self-evident. Consider, for example, the abortion question: is it the woman's prerogative that must prevail or the prerogative of the embryo which, as a person, also has a right to live?

The analysis of rights and duties certifies, but does not quite prove, that rights are born of duties. If we think we have a right to medical treatment, for example, we must remember that this also means that we have a duty to provide that benefit, or at least to seek some guarantee that adequate treatment will indeed be conceded to us. If we believe that we have a right to do research, for example, we must remember that this means that we also have a duty to make sure that the research we are doing brings some benefits to society because, after all, research is essentially a service given to society.

In any case, the pluralism of interests and the varied ways of looking at life cause researchers, in the course of their work, to be met with dilemmas of an ethical nature which can only be solved through dialogue. Because of the increasing consciousness that each individual has the rightful capacity to elaborate his own "truth", religion cannot effectively uphold that certain points of view are unquestionable, as it did in the past. Nonetheless, norms are absolutely necessary when "facts are uncertain, values in dispute, stakes high and decisions urgent" [4]. Dura lex, sed lex.

It is true that the questions brought up by the advance of knowledge are so complex that it is impossible to provide a formula, unique and polished, that provides an answer to them. It has been observed that to respond slowly and inadequately to allegations of research misconduct is typical of institutions [5]. It does not suffice to discuss and theorize; sometimes it is necessary to intervene. This intervention is necessarily realized by means of judgment and concrete propositions, the credibility of which depends partly on rational argumentation and an evident respect for life. It is necessary to establish norms, and follow laws and institutionalize sanctions-equal for all of us-in the sense that all researchers should respect them. In Brazil, that is not quite the way things are.

\section{References}

[1] Pessini, L. and Barchifontaine, C.P. (2007) Problemas Atuais: Bioética. Edições Loyola, São Paulo.

[2] Jonsen, A.R. (2003) The Birth of Bioethics. Oxford University Press, New York. 
[3] (1992) The Rio Earth Summit: Summary of the United Nations Conference on Environment and Development. Science and Technology Division.

[4] Funtowicz, S.O. and Ravetz, J.R. (1993) Science for the Post-Normal Age. Futures, 25, 739-775. http://dx.doi.org/10.1016/0016-3287(93)90022-L

[5] Breen, K.J. (2003) Misconduct in Medical Research: Whose Responsibility? Internal Medicine Journal, 33, $186-191$. http://dx.doi.org/10.1046/j.1445-5994.2003.00373.x 
Scientific Research Publishing (SCIRP) is one of the largest Open Access journal publishers. It is currently publishing more than 200 open access, online, peer-reviewed journals covering a wide range of academic disciplines. SCIRP serves the worldwide academic communities and contributes to the progress and application of science with its publication.

Other selected journals from SCIRP are listed as below. Submit your manuscript to us via either submit@scirp.org or Online Submission Portal.
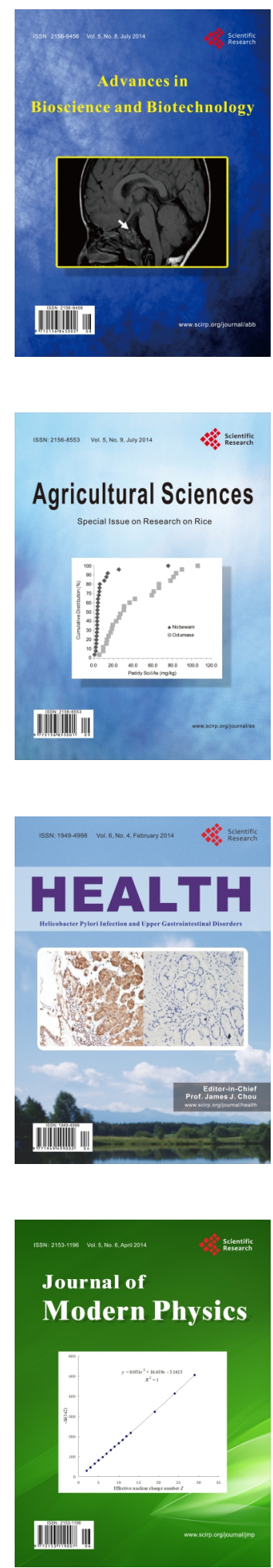
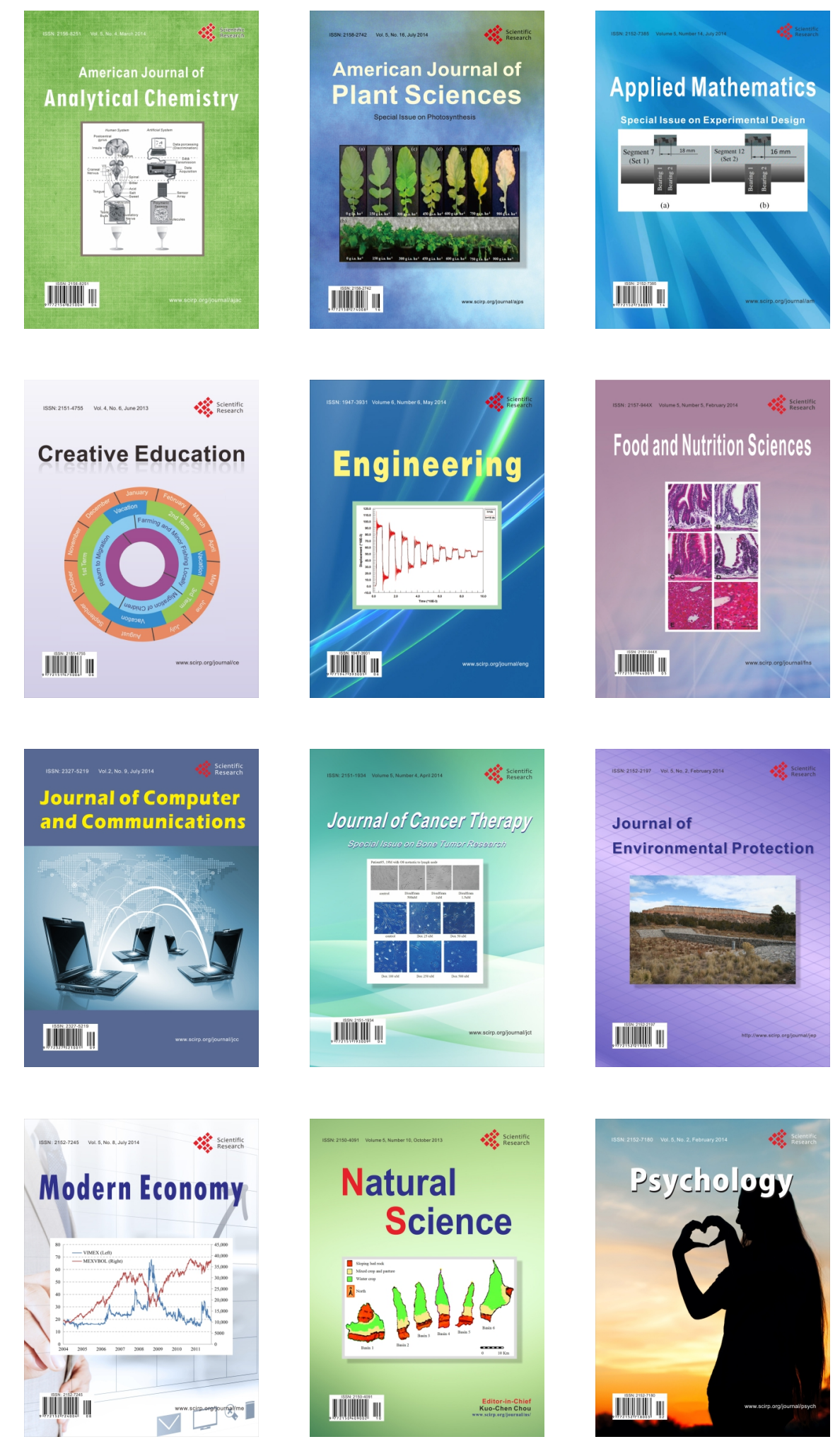